\title{
Türk Bankacılık Sisteminde Kredi Riski ve Modellenmesi
}

Baki DEMIREL, Department of Economics, Faculty of Economics and Administrative Sciences, Gaziosmanpasa University,Turkey; e-mail: baki.demirel@gop.edu.tr

\section{Credit Risk and Modelling in the Turkish Banking System}

\begin{abstract}
An increase in credit risks in the banking sector induces economic risks and therefore affects adversely the financial stability. In reviewing the literature, NLPs are regarded as an important indicator of credit risks. It is therefore important to determine variables that may affect an increase in NLPs in order to achieve the financial stability. The aim of this paper is to analyse the relationship between variables, which are believed to affect NLPs, in the Turkish banking sector and NLPs. For this purpose, Vector Autoregression (VAR) model is used; variables in the model are chosen based on the literature. To study short- and long-run relationship between variables, Johansen Cointegration test and Error Correction Model are applied. This paper makes a contribution to the literature by analysing the link between NLPs in Turkey and 2-year bond yields in the U.S.
\end{abstract}

Keywords : $\quad$ Banking Sector, Credit Risk, NPLs, VAR Model.

JEL Classification Codes : $\quad$ E44, E52, E58, G18.

\section{$\ddot{\mathbf{O} z}$}

Bankacılık sektöründe kredi riskinin artması sektöre ve tüm ekonomiye yönelik riskleri arttırmakta ve finansal istikrarı tehdit etmektedir. Literatürde takipteki krediler (NPLs) bankacılık sektörü kredi riskinin önemli bir göstergesi olarak açıklanmaktadır. Bu bağlamda bankacılık sektöründe risk göstergesi olarak kabul edilen takipteki kredilerin artışına neden olan faktörlerin belirlenmesi finansal istikrar için önemlidir. Bu bilgiler 1şığında çalışmanın amacı Türk bankacılık sektöründe takipteki kredileri etkilediği düşünülen değişkenler ile takipteki krediler arasındaki ilişkiyi analiz etmektedir. Çalışmada söz konusu analiz için VAR modelinden yararlanılmıştır. Modelde yer alan değişkenler literatüre bağlı olarak belirlenmiştir. Değişkenler arasındaki uzun dönem ve kısa dönem ilişkileri belirlemek için Johansen Eş Bütünleşme Analizi ve Hata Düzeltme Modelinden yararlanılmıştır. Çalışma sonucunda, elde edilen diğer bulgulara ek olarak kredi riskiyle ABD 2 yıllık tahvil faizleri arasında ilişki olduğu yönündeki bulgunun literatüre katkı sağlayacağı düşünülmektedir.

Anahtar Sözcükler $\quad$ : $\quad$ Bankacılık Sektörü, Kredi Riski, NPLs, VAR Model. 


\section{Giriş}

2001 Şubat krizi ve sonrasında gelişmeler Türk Bankacılık sektörü için önemli bir milattır. Kriz sonrası bankacılık sektörüne yönelik düzenlemeler, 2002-2009 döneminde görülen sürekli ve kesintisiz büyüme bankacılık sektörünün hem karlılığını arttırmış hem de krizlere karşı daha dayanıklı hale gelmesine olanak sağlamıştır ${ }^{1}$. Nitekim Türk bankacılık sektörü ABD kaynaklı 2008 küresel finansal krizi oldukça dayanıklı karşılamıştır. Güçlü sermaye yapısı, düşük yabancı para riski ve mevduat kaynaklı fonlama yapısı bankaların finansal krize karşı güçlü durmalarına neden olmuştur. Kriz döneminde alınan politika tedbirleri, munzam karşılıklara yönelik uygulanan kararnameler vasıtasıyla karşılıklarda yapılan değişiklikler de bankaların karında ve sermaye oranlarında iyileşme sağlamıştır.

Tablo: 1

\section{Türk Bankacılık Sistemi Bilanço Rasyoları (2008-2013)}

\begin{tabular}{cccccccc}
\hline Yıllar & $\mathbf{2 0 0 8}$ & $\mathbf{2 0 0 9}$ & $\mathbf{2 0 1 0}$ & $\mathbf{2 0 1 1}$ & $\mathbf{2 0 1 2}$ & $\mathbf{2 0 1 3}$ & $\mathbf{2 0 1 4}$ \\
\hline Varlıklar/GSMH & 77.1 & 87.6 & 91.6 & 93.8 & 96.8 & 110.7 & 103.5 \\
Krediler/Toplam Varlıklar & 50.2 & 47.1 & 52.2 & 56.1 & 58.0 & 60.6 & 61.3 \\
DIBS/Toplam Varlıklar & 26.5 & 31.5 & 28.6 & 23.4 & 19.7 & 18.1 & \\
Kredi/Mevduat & 80.8 & 76.3 & 85.2 & 98.2 & 102.9 & 110.7 & 115.3 \\
Kredi Büyümesi (Yıllık Artış) & 28.6 & 6.9 & 33.9 & 29.9 & 16.4 & 31.8 & 16.1 \\
Takipteki Krediler /Toplam Krediler & 3.6 & 5.4 & 3.7 & 2.7 & 2.9 & 2.7 & 2.8 \\
Döviz Kredileri/Toplam Krediler & 28.7 & 26.6 & 27.7 & 29.0 & 26.0 & 26.4 & 27.4 \\
Döviz Mevduatları/Toplam Mevduatlar & 35.3 & 33.7 & 29.7 & 33.9 & 32.6 & 33.4 & 37.1 \\
Sermaye Yeterlilik Oranı & 18.0 & 20.6 & 19.0 & 16.5 & 17.6 & 15.9 & 16.3 \\
Net Aktif Karlılığı (ROA) & 2,5 & 3,3 & 3,0 & 2,2 & 2,4 & 2,5 & 3.5 \\
Net Özkaynak Karlıı̆ı (ROE) & 18,7 & 22,9 & 20,1 & 15,5 & 15,7 & 16,0 & 27.5 \\
\hline Bilanço Dışı İşlemler/Toplam Aktifler & 65,0 & 69,5 & 103,1 & 134,9 & 139,1 & 113.3 & 105,1 \\
\hline
\end{tabular}

Kaynak: BDDK (2006, 2013), IMF (2013b), IMF (2014).

Tablo 1 de görülebileceği gibi Türk bankacılık sektörü krize yüksek sermaye yeterlilik, düşük kaldıraç ve düşük borçluluk girmiş ve bu durum sektörün krize karşı daha dayanıklı olmasına yol açmıştır² (IMF, 2010; TCMB, 2010). Diğger yandan gelişmiş ülkelerin 2008 yılında ortaya çıkan küresel finansal krize karşı uyguladıkları geleneksel olmayan, genişleyici para politikaları (quantatiy easing), Türkiye gibi ülkelere büyük çaplı ve kısa vadeli sermaye akımlarının gelmesine neden olmuştur. Artan yabancı sermaye girişi TL'nin değer kazanmasına, faizler düşmesine, bankacılık sisteminin aşırı kredi genişlemesine

I 2002 Güçlü ekonomiye geçiş programıyla birlikte bankacılık sektörüne yönelik rehabilitasyonun temelinde mali aracılık uzmanlığı olmayan, sermaye yapısı yetersiz, risk iştahı yüksek ve sahiplerince içi boşaltılmış bankaların sistemden ayıklanması ve sektörün gerçek bankacılık işlemlerini yapabilen, yani hane halkı tasarruflarını fiziksel yatırımlara dönüşürebilecek ve bu sayede ekonomik büyümeye ivme kazandıracak bir yapıya dönüştürülmesi amacı vardır (Akkaya \& Gürkaynak, 2012).

2 Elbette bankacılık sisteminin bu dayanıklı yapısında en büyük pay Merkez Bankasının ve 2001-2006 döneminde uygulanan başarılı ekonomi politikalarınındır. Klsaca bu başarı mali disiplin, kuvvetli bankacılık sektörü regülasyonu ve elbette iyi bir Merkez Bankacılı̆̆ının eseridir (Akaya \& Gürkaynak, 2012). 
gitmesine ve yüksek kaldıraç oranlarına neden olarak finansal istikrarı tehdit etmiştir (IMF, 2013a). Artan sermaye hareketlerinin finansal istikrarı tehdit etmesine bağlı olarak fiyat istikrarına odaklı Merkez Bankasının politika yapısı 2011 yılıyla birlikte değişmiş ve fiyat istikrarı yanında finansal istikrar da politika hedefi haline gelmiştir (Başc1, 2012).

Türkiye finansal istikrarsızlığa karşı uygulanan Makro İhtiyati Politika tedbirleriyle 2010 yılının Eylül ayından sonra tanışmıştır. Ancak Merkez Bankası ve BDDK arasındaki çift başlı yapı nedeniyle başarılı biçimde yürütüldüğü söylenemez. Politika tedbiri olarak uygulanan zorunlu karşılık oranlarının arttırılması ve faiz koridoru politikası bankacılık sektöründe beklenen etkiyi göstermemiştir ${ }^{3}$. Burada amaç bankaların aşırı kredi genişlemesinin (veya kredi artış hızının) önüne geçmek olmasına rağmen, Tablo 1'de görülebileceği gibi bankalar mevduat yerine diğer fonlama kaynaklarına yönelerek kredi büyümesini azaltmamışlardır. Daha açık olarak TCMB sorunun tespiti yani kredi büyümesinin azaltılmasına yönelik politikasında haklıdır ancak bunu sağlayacak araçların bir kısmının BDDK kontrolünde olması politika başarısızlığı getirmiştir (Akkaya \& Gürkaynak, 2012).

Özetle, büyük merkez bankalarının küresel risk iştahını arttıracak (risk on) biçimindeki krize karşı politikaları Türkiye'de finansal istikrarı tehdit edecek veya riski arttıracak sonuçlara neden olmuştur. Politika faiz oranının azalması ve faizlerin düşmesi bankacılık sektörünün daha riskli varlıklara veya riski yüksek kredi tercihlerine yönelmesine neden olmuştur. Artan riskli tercihlere ve kaldıraçların yükselmesine bağlı olarak 2012 yılında bankacılık sektörünün karında artış gerçekleşmiştir (EK 3 de yer alan Grafik 2: ROE, Grafik 3: ROA dizileri), ancak bu durum sektörü tehdit edebilecek sonuçların doğmasına neden olabilecektir.

Bu bağlamda bankacılık sistemi için en çarpıcı gelişmenin 2010 yılından itibaren sürekli artan Kredi/Mevduat oranında olduğunu söylenebilir. Bu durum bankacılık sisteminin kaldıraçlarının da artış eğiliminde olduğunu yansıtmaktadır. 2008 yılında \%81 olan Kredi/Mevduat oran1 2013 yılında \%110 seviyesine yaklaşmıştır. Bunun sonucu olarak artan Krediler/Toplam Varlıklar oranındaki eğilim, sistemin sağlıklı bir yapıya yöneldiğinin bir göstergesi olarak düşünülebilir. Diğer yandan \%16 civarında olan sermaye yeterlilik oranı sektörün sermaye yapısının hala çok güçlü olduğu göstermektedir. İşletmelere verilen yabancı para cinsinden krediler dolaylı olarak sistemin asıl sorununu oluşturmaktadır. Döviz

3 IMF (2013b) Türkiye için yaptı̆̆ değerlendirme raporunda para politikasına yönelik en temel eleştiriyi faiz koridoru üzerinden gerçekleştirmiştir. Article IV Türkiye ekonomisine değerlendirmelerinde para politikası uygulamasına yönelik eleştirilerde bulunmuştur. Bu eleştirilerin temelinde TCMB para politikası çerçevesinin iyi anlaşılmadığ v ve karmaşık olduğu düşüncesi yatmaktadır. Para politikası, kriz sonrası birden fazla hedef için çok sayıda araç kullanılarak yapılmıştır. Fiyat istikrarının yanında kısa vadeli sermaye girişlerinin istikrar bozucu etkilerini (volatiliteyi) engellemek yoluyla finansal istikrar amaçlanmıştır. Ayrıca TCMB dolaylı olarak ekonomik büyümeyi destekleyici adımlar atmasına karşın uygulama sonrasi hedeflerin yeterince gerçekleştirilmediği görülmektedir. 
kurundaki büyük bir değişiklik finansal olmayan şirketlerin üstlendikleri kur riskinin bankalara yayılmasına neden olabilir. Böyle bir senaryo altında takipteki krediler (NPLs: Non Performing Loans) artacağından sistem üzerinde finansal stresin birikmesine yol açabilir. Bankacılık sistemi için tehlike oluşturabilecek diğer bir konu 2010 yılından itibaren bilanço dışı işlemlerin hızlı artış göstermesidir. Bankacılık sektörünün daha yüksek kaldıraçlarla çalışmasına yol açan bu gelişme sektör üzerindeki risklerin artmasına neden olabilecektir. Tablo 1'ye baktığımızda bilanço dışı işlemlerin toplam aktifler içindeki payının 2008 yılında \%65, 2013 yılında ise \%152 olduğu görülmektedir.

Yukarıda açıklanan bilgiler 1şığında bu çalışmanın amacı Türk bankacılık sisteminin kredi riskini belirlediği düşünülen yurt içi ve yurt faktörler ile kredi riski arasındaki ilişkiyi analiz etmektir. Türk bankacılık sektörünün 2003-2014 dönemini ele alan ve kredi riski olarak takipteki kredilerin vekil (Proxy) değişken seçildiği çalışmada takipteki kredileri etkilediği düşünülen yurt içi ve yurt dışı faktörler ile takipteki krediler arasındaki iliş̧ki kısa dönem ve uzun dönem olarak ayrı ayrı ele alınmış ve VAR modelinden yararlanılmıştır. Yapılan analiz sonucu elde edilen en çarpıcı bulgu, volatilite endeksi (VIX) ve ABD2 (USA2Y) ile takipteki krediler arasında istatistiki olarak anlamlı ve güçlü bir ilişkinin bulunmasıdır. Söz konusu bulgunun takipteki kredileri belirleyen faktörleri ele alan Türkçe literatüre önemli bir katkı olduğu düşünülmektedir. Çalışma ayrıca Türk bankacılık sektörünün kredi riski sorununu detaylı biçimde ele alması ve politika önerileri ile de literatüre katkı sağlamaktadır.

Çalışma giriş ve sonuç bölümleri dâhil dört bölümden oluşmaktadır. Giriş bölümünü takip eden birinci bölüm literatür özeti biçimindedir. İkinci bölümde kullanılacak model, ekonometrik yöntem ve veri seti tanıtılacak ve yapılan analizler sonucu elde edilen bulgular açıklanacaktır. İkinci bölümü bulguların değerlendirildiği sonuç bölümü takip edecektir.

\section{Literatür Özeti}

Literatür özeti yapılırken çalışmanın genel çerçevesine uygun olduğu düşünülen iki temel konuya odaklanılmıştır. Öncelikle, kredi riskinin finansal sistem içindeki önemini ve finansal kırılganlıkla ilişkisini konu edinen literatüre yer verilmiştir. Daha sonra kredi riskini belirleyen faktörleri araştıran literatür özetlenmiştir.

Bankacılık sisteminde oluşan kredi riskinin finansal sistemin tamamı ve reel sektör üzerinde risk oluşturacağ literatürde tartışılan önemli bir konudur. Bankacılık sektörü kaynaklı risklerin finansal krizlerin ortaya çıkmasında ne derece etken oldukları finansal sermaye hareketlerinin hızlandığı 1990'ların başından itibaren bu alandaki literatürün temel tartışma konularından biri olmuştur. Yaşanan son küresel finansal kriz de, finansal krizlere ait erken uyarı işaretlerinin ne kadar önemli olduğunun anlaşılmasına zemin hazırlamıştır. Finansal Sağlamlık Oranları (FSIs) finansal sistemin sağlıklı yapıya sahip olup olmadığını ölçen en önemli göstergeler arasındadır. Bu oranların zaman içindeki değişimleri finansal sistemin potansiyel kırılganlığını ve olası zayıflıklarını gösterir. 
Navajas ve Thegeya (2013), IMF (2013a), Cihak ve Schaeck (2007), DemirgüçKunt ve Detragiache (1998) çalışmaları FSIs'in potansiyel banka krizini yansıtmakta ve gelişen piyasa ekonomilerinin banka krizlerini açıklamada yüksek kabiliyet gösterdiğini ortaya koymuşlardır. Navajas ve Thegeya (2013), Demirgüç-Kunt ve Detragiache (1998), çok değişkenli Logit Model kullanarak yaptıkları analizler, Ana Sermaye/Risk A ğırlıklı Varlıklarının (CAR), NPLs'in ve Öz Sermaye Karlılık Oranının (ROE) en önemli kriz öncü göstergeleri olduklarına işaret etmektedir. Düşük CAR ve yüksek NPLs değerleri finansal sistemin zayıflığını gösterirken, ROE kriz dönemini yansıtan önemli bir gösterge değişkendir. Demirgüç-Kunt ve Detragiache banka krizlerinin yüksek enflasyon, yüksek faiz ve düşük büyümeyi takip ettiklerini belirtmişlerdir.

Banka kredilerinin finansal sistem ve ekonomi için önemi ve banka kredilerindeki artışı belirleyen faktörler Dell Ariccia vd. (2012), Valancia (2011) ve Gray vd. (2014) çalışmaları tarafından ele alınmıştır. Bu çalışmalara göre net sermaye hareketlerindeki artış kredi büyümesini tetiklemekte ve bankaların kredi verirken rahat davranmalarına ve riski arttırmalarına neden olabilmektedir. Ayrıca sermaye hareketlerindeki artışa bağlı olarak para politikası faiz oranındaki azalmanın bankaların risk üstlenici davranışlarını arttırdığı belirtilmektedir Risk üstlenici davranışlar kaldıraç oranın yükselmesine neden olmaktadır. Kredi olanaklarının sınırlanması bankaların daha riskli varlıklara yönelmelerine ve iflas riskinin artmasına da yol açabilecektir. Bunlara ilave olarak Fernandez vd. (2000) çalışmasında da belirtildiği gibi de-regülasyonlar veya kredi koşullarının gevşetilmesine yönelik düzenlemeler kredi genişlemesine neden olabilmekte ve bankaların daha fazla risk almasına ve kredi risklerini arttırmalarına yol açmaktadır.

Kredi riski üzerine yapılan çalışmaların pek çoğu NPLs oranı üzerine odaklanmıştır. Söz konusu literatür NPLs'i etkileyen faktörlerin belirlenmesi üzerine olduğu gibi spesifik olarak belirli faktörlerle NPLs arasındaki ilişki üzerine de olmaktadır.

Ebeke vd. (2014), Kim ve Mitra (2014), De Bock ve Demyanets (2012), Nkusu (2011) Espinoza ve Prasad (2010) ve Vazquez vd. (2010), NPLs etkileyen en önemli faktörler olarak ekonomik, büyüme, ekonomik büyümenin volatilitesi ve kişi başına düşen gelirin düzeyi ön plana çıkarmışlardır. Söz konusu çalışmalar ekonomilerin genişleme dönemlerinde bankaların kredi riski azalırken daralma dönemlerinde arttığını ifade etmektedirler. Yazarlara göre, genişleme döneminde GSYİH büyümesindeki aşırılık bankaların risk üstlenimini arttırarak daralma dönemlerinde banka risklerinin yükselmesine neden olmuştur.

Klein (2013), 1998-2011 dönem aralığında panel VAR (panel vector autoregression) analizi kullanarak Merkez, Doğu ve Güneydoğu Avrupa ülkelerinde (CEES) NPLs'i etkileyen faktörlerin belirlenmesini ele almıştır. Klein'e göre; NPLs, makro ekonomik ve banka spesifik faktörler tarafından etkilenmektedir. Ülke para biriminin değer kaybı, işsizlik oranı artışı, yüksek enflasyon ve VIX artışı NPLs üzerinde pozitif etkiye sahiptir. Ayrıca ROE ve NPLs arasında negatif, Krediler / Varlıklar oranı ve NPLs arasında pozitif yönlü ilişki saptanmıştır. 
Jabuik ve Reininger (2013), 2004-2012 döneminde panel GMM (Generalized Method of the Moments; Arellano \& Bond, 1991) kullanarak CEES için NPLs’i belirleyen faktörleri tahmin etmişlerdir. Çalışmada NPLs gecikme değerleri, reel GSYİH, borsa indeksi, Özel Sektöre Verilen Krediler/Reel GSYIH oran1, Yabancı Para Cinsinden Krediler/Toplam Krediler oranı açıklayıcı değişkenler olarak belirlenmişlerdir. Çalışma sonucunda reel GSYİH hariç diğer açıklayıcı değişkenlerle NPLs arasında pozitif yönlü ilişki saptanmıştır.

Makri vd. (2013), 2000-2008 döneminde Euro Bölgesi için NPLs’i belirleyen faktörleri analiz etmişlerdir. Çalışmada 17 Avro bölgesi ülkesinin 14'ü ele alınmış ve panel GMM kullanılmıştır. Bankacılık sektörüne özel değişkenler (Kârlılık Oranları; ROA ve ROE, Banka Sermayesi + Mevduatlar/Varlıklar Oranı, Krediler/Mevduatlar Oranı) ve makroekonomik değişkenlerin (Kamu Borç Stoku/GSYİH, Kamu Bütçe Açı̆̆ı/GSYİH, GSYİH Büyümesi, Enflasyon ve İşsizlik oranları) açıklayıcı değişken olarak ele alınmıştır. Elde edilen bulgular, Banka Sermayesi + Mevduatlar/Varlıklar Oranı ve ROE ile NPLs arasında negatif, İşsizlik Oranı ve Borç Stoku/GSYİH oranı ile NPLs arasında ise pozitif yönlü ilişki olduğu biçimindedir. Diğer açıklayıcı değişkenlerle NPLs arasında istatistikî olarak anlamlı ilişkiye rastlanılmamıştır.

Pouvelle (2012), 1993-2010 döneminde üç aylık frekansa dayalı panel veri analizi uygulayarak Fransa için varlık fiyatları ve bankaların kredi büyümesi ilişkisini açıklamaya çalışmıştır. Pouvelle, varlık fiyatlarındaki artışla NPLs arasında korelasyon bulamamıştır. Buna karşın reel GSYİH büyümesi ile NPLs arasında pozitif bir korelasyon elde etmiştir. Taşınmaz malların fiyatları ile NPLs arasında ise negatif bir korelasyon olduğu gözlemlenmiştir. Ayrıca kredi büyümesi ile NPLs arasında pozitif bir korelasyon bulgusuna rastlanmıştır.

Türk bankacılık sisteminin kredi riskinin belirlenmesine yönelik bu çalışmada NPLs yukarıda açıklanan literatüre bağlı olarak kredi riski için vekil (proxy) değişken olarak kabul edilmiştir. Çalışmanın bundan sonraki aşaması yine literatüre bağlı olarak tespit edilen ve NPLs'i etkilediği düşünülen değişkenlerle NPLs arasındaki ilişkinin ekonometrik olarak analiz edilmesine yönelik olmuştur.

\section{Veri Seti Model ve Yöntem}

\subsection{Veri Seti ve Model}

Bankacılık sektörü kredi riskini etkileyen değişkenlerin tahmin edilmesine yönelik bu çalışmada VAR modeli kullanılmıştır. VAR modeli ile makroekonomik şokların (yurtiçi ve yurtdışı şokların=faktörlerin) takipteki krediler (Non-performing loans, NPLs) üzerindeki etkisi analiz edilmiştir. VAR modelinin tercih edilmesinin nedeni modelin makroekonomik değişkenlerin analizine uygun olmasıdır. 
Değişkenler arasında uzun dönem ilişkinin varlığı veya yokluğu Johansen Eşbütünleşme (Co-integration) analiziyle araştırılmıştır. Eş bütünleşeme analizinin bulgularına göre değişkenler arasındaki kısa dönem ilişkisinin analizi için hata düzeltme modelinden (ECM; Error Corection Model) yararlanılmıştır.

2003-2014 yılları arası üç aylık zaman serileri kullanılarak yapılan analizlerde yer alan değişkenler: Büyüme oranı, VIX (volatilite endeksi) ${ }^{4}$, ABD 2 yıllık tahvilleri, sanayi üretim endeksi, yurtiçi reel kredi büyümesi, cari açık, döviz kuru (TRY/USD birinci dereceden logaritmik farkı) ve kredi riskini temsilen NPLs alınmıştır.

Çalışmada yer alan değişkenlere ait seriler Thomson data stream, TCMB (EVDS) ve BDDK veri bankalarından elde edilmiştir. Temel regresyon denklemi aşağıdaki biçimdedir:

$$
N P L s_{i t}=\beta+\alpha X_{i t}+\varepsilon_{i t}
$$

Burada NPLs; takipteki kredileri, beta; kesişim değerini, $\mathrm{X}$ ise takipteki kredileri etkilediği düşünülen değişkenler matrisini, $\varepsilon$, ise hata terimini simgelemektedir. $X$ matrisinde yer alan değişkenleri de kapsayacak biçimde model bir fonksiyon olarak aşağıdaki biçimde yazılabilir:

$$
N P L s_{t}=f\left(G_{t}, C A_{t_{t}} U S A 2 Y_{t}, V I X_{t}, R C G_{t}, R E E R_{t}, M P I_{t}, S T O C K_{t}\right)
$$

Burada, G; büyüme oranı, CA; cari açık, USA2Y, ABD 2 yıllık bono, VIX, volatilite endeksi, RCG; reel kredi büyümesi, REER, döviz kuru; MPI; sanayi üretim endeksi, STOCK; Borsa İstanbul endeksi, olarak simgelenmiştir.

Veri setine ilişkin tanımlayıcı istatistikler Tablo 2 de gösterilmiştir. Tabloya göre kredi genişlemesi ve volatilite endeksi hariç diğer tüm değişkenler normal dağılım göstermektedir. Elde edilen bu bulguya ve literatüre dayalı olarak değişkenlere ait birim kök sınamasında Genelleştirilmiş Dickey-Fuler (ADF) testinin kullanılmasına karar verilmiştir. Çalışmaya ait birim kök sınaması yöntem bölümünde yer almaktadır.

4 VIX, Chicago Borsası volatilitesini yansıtmaktadır aynı zamanda küresel risk iştahını gösterir ve korku endeksi olarak da ifade edilir. 
Tablo: 2

Tanımlayıcı İstatistikler

\begin{tabular}{cccccccccc}
\hline & NPLS & G & RCG & RER & MPI & CA & STOCK & USA2Y & VIX \\
Ortalama & 4882,05 & 3,51 & 7,12 & 114,07 & 105,00 & $-8975,31$ & 46828,51 & 1,70 & 19,86 \\
Std, Hata, & 3707,67 & 8,66 & 4,78 & 8,64 & 13,33 & 5800,02 & 21033,07 & 1,76 & 8,03 \\
Çarpıklı & 0,30 & 0,23 & 1,13 & $-0,21$ & $-0,18$ & $-0,43$ & $-0,02$ & 0,68 & 1,47 \\
Basıklık & 1,80 & 1,92 & 4,81 & 2,95 & 2,21 & 2,57 & 1,95 & 1,97 & 4,83 \\
Jarque-Bera & 3,56 & 2,77 & 16,74 & 0,35 & 1,50 & 1,86 & 2,21 & 5,80 & 24,13 \\
Olasılık & 0,17 & 0,25 & 0,00 & 0,84 & 0,47 & 0,39 & 0,33 & 0,06 & 0,00 \\
Gözlem & 48,00 & 48,00 & 48,00 & 48,00 & 48,00 & 48,00 & 48,00 & 48,00 & 48,00 \\
\hline
\end{tabular}

Not: Jargue-Bera normal dağılım test sonuçlarını vermektedir. Null hipotez serilerin normal dağılımını verir Asteriks * işareti verilen seriler normal dă̆ılmadı̆̆ını gösterir.

\subsection{Yöntem}

Eş-bütünleşme analizi varsayımlarımdan birisi de durağanlıkla ilgili olduğundan değişkenlerin durağanlığı sınanmalıdır. Değişkenlerin durağanlığının sınanmasında ADF, PP ve KPSS gibi birim kök testleri kullanılabilmektedir. Bu testler de bir zaman serisi birim kök içermiyorsa durağan kabul edilmektedir. Bu çalışmada (ADF) (Dickey \& Fuller, 1979) kök testleri kullanılmıştır. Birim kök testlerinin sonuçları, Tablo 3 'de gösterilmiştir.

Durağanlık sınamasına göre tüm değişkenlerin düzeyde durağan olmayıp birinci sıra farklarının durağan oldukları anlaşılmıştır. Bu durum tüm değişkenler arasında eş bütünleşme analizi yapılmasına imkân tanımaktadır. Eş bütünleşme analizi için Johansen ve Juselius (1990) çalışmasında geliştirilen yöntem kullanılmıştır.

Tablo: 3

\section{Çalışmanın Değişkenlerine Ait Durağanlık Testleri (ADF)}

\begin{tabular}{ccc}
\hline \hline SERİLER & DÜZEY & BíRİNCI SIRA FARKLAR \\
NPLs & 1.4891 & $-4.0904 * * *$ \\
G & -2.0104 & $-8.6374 * * *$ \\
CA & -2.6738 & $-8.1202^{* * *}$ \\
USA2Y & -1.5859 & $-5.0205^{* * *}$ \\
VIX & -2.7533 & $-7.0746 * * *$ \\
RCG & -1.8580 & $-5.1499 * * *$ \\
REER & -0.2437 & $-6.5024 * * *$ \\
MPI & -1.9552 & $-13.2539 * * *$ \\
STOCK & -2.2527 & $-2.9937 * *$ \\
\hline
\end{tabular}

Not: Asteriks, *** olan yerlerde $1 \%$ anlamlıllk düzeyine göre, ** olan yerlerde $5 \%$ anlamlllık düzeyine göre null hipotezi reddedilerek serilerin durağan olduğunu öngören alternatif hipotez kabul edilmişstir. ADF testi için kullanılan gecikme sayısını Eviews 8.0 ekonometrik paket programının otomatik olarak seçtiği değer kabul edilmişstir.

Johansen ve Juselius (1990), eş bütünleşme hipotezini test etmek için en çoklu benzerlik yöntemi (Maximum Likelihood Estimation) ve Likehood Ratio testlerini geliştirmişlerdir. Aşağıdaki Tablo 4, tahmin denklemimizde yer alan değişkenler için 
yapılan Johansen Eş-bütünleşme test sonuçlarını göstermektedir. İz (Trace) Testi bulguları değişkenler arasında 10 eş bütünleşme ilişkisi olduğunu gösterirken, Maksimum Öz-Değer (Maximum Eigenvalue) Testine göre değişkenler arasında 6 eş bütünleşme ilişkisi vardır. Ancak özellikle iki veya daha fazlı değişken arasında eş bütünleşme ilişkisinin arandığı durumlarda İz (Trace) test bulguları daha fazla tercih edilir olmaktadır (Lütkepohl, Saikkonen, Trenkler; 2000). Analiz bulgularına göre seçilmiş değişkenlerin tamamı arasında eş bütünleşme ilişkisin var olduğunu söylenebilir.

Eş-bütünleşe testlerinden elde edilen bulgular tüm değişkenler arasında uzun dönem ilişkinin varlığını göstermektedir. Daha açık olarak NPLs ve seçilmiş değişkenler arasında uzun dönem dengesinin olduğunu söyleyebiliriz. Bu bulgular söz konusu değişkenlerin kredi riskini uzun dönemde belirleyen faktörler olabilecekleri biçiminde yorumlanabilir. Johansen Eş-bütünleşme analizi ile fonksiyonel ilişkide tanımlı değişkenler arasında uzun dönem ilişkisi belirlendikten sonra söz konusu değişkenler arasında kısa dönem ilişkisinin varlığı veya yokluğu Hata Düzeltme Modeli ile belirlenebilecektir. Dolayısıyla analizin bundan sonraki aşaması Hata Düzeltme Modeli olacaktır.

Tablo: 4

Johansen Eş Bütünleşme Testi Sonuçları

\begin{tabular}{cccc}
\hline Sıfır Hipotezi & Iz Testi & Sıfır Hipotez & Maksimum Öz-Değer Testi \\
$\mathrm{r} \leq 0$ & $406.03^{* * *}$ & $\mathrm{r}=0$ & $96.27 * * *$ \\
$\mathrm{r} \leq 1$ & $307.76^{* * *}$ & $\mathrm{r}=1$ & $60.84 * *$ \\
$\mathrm{r} \leq 2$ & $248.91 * * *$ & $\mathrm{r}=2$ & $57.42 * *$ \\
$\mathrm{r} \leq 3$ & $191.49 * * *$ & $\mathrm{r}=3$ & $51.33 * *$ \\
$\mathrm{r} \leq 4$ & $140.15 * * *$ & $\mathrm{r}=4$ & $43.51 * *$ \\
$\mathrm{r} \leq 5$ & $96.64 * * *$ & $\mathrm{r}=5$ & $41.06 * * *$ \\
$\mathrm{r} \leq 6$ & $55.58^{* * *}$ & $\mathrm{r}=6$ & 22.05 \\
$\mathrm{r} \leq 7$ & $33.52 * *$ & $\mathrm{r}=7$ & 16.30 \\
$\mathrm{r} \leq 8$ & $5.56 * *$ & $\mathrm{r}=8$ & $5.56 * *$ \\
\hline
\end{tabular}

Not: $r$, eş bütünleşme vektör saylsını göstermektedir. Asteriks***, ** sırasıyla \%1 ve \%5 anlamlılık düzeyinde null hipotezini (seriler arasında eş bütünleşme yoktur) reddedildiğini gösterir. Kullanılan kritik değerler varsayımlara göre (örneğin: doğrusal trend, sabit değer) farklılık göstermektedir. Johansen öncesi VAR gecikme sayısı 1 alınmiştır.

\subsection{Bulgular}

\subsubsection{Hata Düzeltme Modeli}

“Eş-bütünleşme” analizi sonucu elde edilen bulgular bütün değişkenlerle NPLs arasında uzun dönem ilişkisinin varlığını göstermektedir. Uzun dönem ilişki saptanan değişkenler arasında kısa dönem ilişkinin varlığ 1 ve yokluğunun analizinde ve söz konusu fonksiyonel ilişkide görülebilecek kısa dönem sapmaların tekrar dengeye ulaşıp ulaşmayacağının belirlenmesinde "Hata Düzeltme Modelinden (VEC-Vector Error Correction: ECM)” yararlanılmaktadır. ECM modelini uygulamak için Eşitlik (1) elde edilen 
hata teriminin bir gecikme değerini Eşitlik (2) de bağımsız değişken olarak katılacaktır. Hata Düzeltme Modeli bulguları aşağıdaki Tablo 5 de gösterilmiştir.

$$
\Delta N P L s_{i t}=\beta+\alpha \Delta X_{i t}+\gamma e c m_{(-1)}+v_{i t}
$$

Hata düzeltme modelinde yer alan değişkenler arasındaki bağımlılık ilişkisini sınamak üzere korelasyon analizi yapılmış ve Ek-2 de gösterilmiştir. Ek-2 Tablo 1'de gösterilen analiz bulguları cari açık, borsa ve ABD 2 yıllık tahviller ile takipteki krediler arasında istatistiki olarak anlamlı güçlü, kredi büyümesi ve sanayi üretim endeksi ile takipteki krediler arasında ise istatistiki olarak anlamlı zayıf korelasyon olduğu yönündedir. Bağımsız değişkenlerin kendi aralarındaki ilişkide ise sadece borsa ve cari açık arasında negatif ve istatistiki olarak anlamlı güçlü korelasyona rastlanmıştır. Sonuç olarak elde edilen korelasyon bulguları değişkenler arasında oto-korelasyon ilişkisi olmadığı biçiminde yorumlanabilir. Ek-2 Tablo 2 de gösterilen oto-korelasyon sinamasina ait bulgularda bu yorumu desteklemektedir.

Tablo: 5

Hata Düzeltme Modeli Bulguları

\begin{tabular}{cccc}
\hline \hline Değişkenler & Katsayılar & Std. Sapma & Olasillk \\
Kesişim & $1078.020^{* *}$ & 404.9920 & 0.0124 \\
DCA(-2) & $0.097051^{* * *}$ & 0.026914 & 0.0011 \\
DREER & 980.1477 & 1155.574 & 0.4030 \\
DG(-2) & $-4383.154 * *$ & 1864.755 & 0.0255 \\
DVIX(-4) & $50.8694^{* * *}$ & 15.10298 & 0.0021 \\
DRCG(-1) & 8.243417 & 18.82698 & 0.6646 \\
DMPI(-3) & $-58.76091 * * *$ & 15.81961 & 0.0008 \\
DSTOCK(-3) & $-0.049864^{* *}$ & 0.019787 & 0.0173 \\
DABD2Y(-3) & $1219.755^{* * *}$ & 283.9938 & 0.0002 \\
ECM(-1) & $-0.731387^{* * *}$ & 0.154071 & 0.0000 \\
AR(1) & $0.731081^{* * *}$ & 0.117031 & 0.0000 \\
$\mathbf{R}^{2}$ & Adj. $\mathbf{R}^{2}$ & Durbin-Watson ist. & Olasiluk (F-ist.) \\
0.713803 & 0.618404 & 1.511167 & 0.000008 \\
\hline
\end{tabular}

Not: Hata Düzeltme Modeli için Eviews 8.0 kullanılmıştır. Asteriks **,*** işaretleri sırasılyla \%5 ve \%1 anlamlılık düzeyini göstermektedir.

Tablo 5 bulgularına göre reel kredi genişlemesi (RCG) ve reel döviz kuru (REER) ile takipteki krediler (NPLs) arasında kısa dönemde de istatistiki olarak anlamlı ilişki bulunamamıştır. Yurt içi değişkenler olarak kabul edebileceğimiz, borsa (STOCK), sanayi üretim endeksi (MPI) ve ekonomik büyüme (G) ile NPLs arasında negatif ve istatistiki olarak anlamlı ilişki bulunmuştur. Buna karşılık (CA) ile NPLs arasında pozitif ve istatistiki olarak anlamlı ilişki olduğu sonucuna ulaşılmıştır. Elde edilen bulgular ve değişkenlerin işaretleri literatürle tutarlılık göstermektedir. Diğer yandan Reel döviz kuru (REER) ve reel kredi genişlemesinin (RCG) NPLs üzerinde istatistiki olarak anlamsız etkiye sahip olmaları beklentilerimizle uyumsuzdur. 
Küresel faktörler olarak kabul edebileceğimiz küresel risk iştahı (VIX) ve ABD iki yıllık hazine bonolarının faizi (USA2Y) ile NPLs arasında pozitif ve istatistiki olarak anlamlı ilişki olduğu görülmektedir. USA2Y bir anlamda FED (ABD Merkez Bankası) için bir sinyal görevi göstermektedir ve FED politika faizinin aratacağ bonoların faizlerini de yükseltmektedir. Küresel risk iştahının kapanması (VIX artışı) veya ABD tahvillerinin getirisinin artması uluslararası sermayenin Türkiye gibi gelişmekte olan ülkelerden çıkmasına neden olabilecek faktörlerdir. Böyle bir durumda gelişmekte olan ülkelerin para birimleri değer kaybedeceğinden kur riski taşıyan firmalar bankalara borçlarını ödeyemeyeceklerdir. Bu durum takipteki kredilerde artışa neden olabilecektir.

\subsubsection{Varyans Ayrıştırma}

VAR modeline bağlı olarak varyans ayrıștırması hesaplamasının yapılabilmesi için ele alınan serilerin durağan olması gerekir. Aksi takdirde durağan olmayan serilerle yapılan hipotez testleri kuşkulu hale gelmektedir. Bu nedenle çalışma içerisinde varyans ayrıştırma hesaplaması yaparken ele alınan serilerin birinci sıra farkları dikkate alınmıştır. Varyans ayrıştırması hesaplaması sonuçları aşağıdaki Tablo 6'da gösterilmiştir. Tablo, 24 dönem olarak düzenlenmiştir. İlk 8 dönem kısa ve orta dönemi 9-24 arası dönemler ise uzun dönemi kapsamaktadır.

Tablo: 6

Varyans Ayrıştırma Hesaplaması Bulguları

\begin{tabular}{cccccccccc}
\hline \hline Dönemler & DNPLS & DABD2Y & DVIX & DMPI & DSTOCK & DG & DRCG & DCA & DREER \\
1 & 100,0 & 0,0 & 0,0 & 0,0 & 0,0 & 0,0 & 0,0 & 0,0 & 0,0 \\
2 & 85,4 & 2,1 & 0,0 & 5,2 & 1,6 & 0,4 & 3,2 & 0,0 & 2,0 \\
3 & 68,9 & 1,7 & 4,4 & 4,8 & 7,1 & 3,1 & 2,5 & 5,8 & 1,6 \\
4 & 57,9 & 4,2 & 5,0 & 4,8 & 15,4 & 2,9 & 2,3 & 6,0 & 1,4 \\
5 & 50,6 & 7,1 & 12,4 & 4,3 & 13,9 & 2,5 & 2,3 & 5,3 & 1,4 \\
6 & 47,4 & 9,1 & 13,2 & 4,0 & 15,6 & 2,3 & 2,2 & 4,8 & 1,3 \\
7 & 46,0 & 9,6 & 14,0 & 4,4 & 15,4 & 2,3 & 2,1 & 4,7 & 1,4 \\
8 & 42,0 & 12,4 & 12,9 & 4,3 & 15,8 & 3,7 & 2,3 & 4,7 & 2,0 \\
9 & 39,0 & 15,8 & 11,8 & 4,1 & 16,9 & 3,8 & 2,1 & 4,3 & 2,2 \\
10 & 38,4 & 16,3 & 11,6 & 4,1 & 16,8 & 4,1 & 2,0 & 4,3 & 2,5 \\
11 & 37,5 & 16,6 & 11,3 & 4,1 & 17,1 & 4,1 & 2,2 & 4,6 & 2,5 \\
12 & 37,2 & 16,4 & 11,2 & 4,4 & 16,9 & 4,3 & 2,3 & 4,6 & 2,8 \\
13 & 37,1 & 16,2 & 11,6 & 4,5 & 16,7 & 4,3 & 2,4 & 4,5 & 2,8 \\
14 & 36,7 & 16,0 & 11,9 & 4,4 & 17,1 & 4,2 & 2,4 & 4,4 & 2,8 \\
15 & 36,3 & 15,8 & 12,2 & 4,7 & 16,9 & 4,5 & 2,3 & 4,4 & 2,8 \\
16 & 36,2 & 15,9 & 12,2 & 4,8 & 16,8 & 4,5 & 2,3 & 4,5 & 2,9 \\
17 & 35,8 & 15,8 & 12,0 & 5,0 & 17,2 & 4,5 & 2,3 & 4,6 & 2,8 \\
18 & 35,6 & 15,8 & 12,0 & 5,0 & 17,2 & 4,5 & 2,5 & 4,6 & 2,8 \\
19 & 35,3 & 15,7 & 12,0 & 5,2 & 17,5 & 4,5 & 2,4 & 4,5 & 2,8 \\
20 & 35,1 & 15,6 & 12,1 & 5,4 & 17,4 & 4,5 & 2,4 & 4,5 & 2,9 \\
21 & 35,1 & 15,5 & 12,0 & 5,6 & 17,5 & 4,5 & 2,4 & 4,5 & 2,9 \\
22 & 34,9 & 15,4 & 11,9 & 5,8 & 17,7 & 4,5 & 2,5 & 4,5 & 2,9 \\
23 & 34,7 & 15,3 & 11,9 & 6,0 & 17,6 & 4,6 & 2,5 & 4,5 & 2,9 \\
& 34,5 & 15,4 & 11,8 & 6,2 & 17,6 & 4,6 & 2,4 & 4,5 & 2,9 \\
\hline
\end{tabular}

Not: Tablo bulguları yazar tarafindan hesaplanmıştır. 
Varyans Ayrıştırma hesaplaması bulguları bağımsız değişkenlerden kaynaklı şokların bağımlı değişkende (NPLs) meydana gelen değişmeleri açıklama gücünü vermektedir. Buna göre NPLs değişmeleri kısa-orta ve uzun dönemde açıklama gücü en fazla olan değişkenlerin, VIX, USA2Y ve STOCK olduğu görülmektedir. Bu bulgular, NPLs de meydana gelen değişimlerin daha çok dişsal şoklar kaynaklı olduğu biçiminde yorumlanabilir.

\subsubsection{Etki Tepki Analizi}

Enders (1995)'e göre VAR modeline dayalı Etki Tepki Analizi, modelde yer alan değişkenlerin hata terimleri kaynaklı şokların diğer değişkenler üzerindeki etkisini göstermektedir. Bu çalışmada etki tepki (Impulse-Response) analizi bulguları EK-1 de gösterilmiştir. EK-1 de yer alan grafikler yurt içi ve yurt dışı kaynaklı şoklar karşısında NPLs'in kısa dönem tepkilerini göstermektedirler. Daha açık olarak grafikler ilk dört dönem tepkileri yansıttığından şokların etkilerinin zamanla ortadan kalktığı görülmemektedir. Bunun nedeni yurt içi ve yurt dışı kaynaklı şoklar karşısında NPLs'in kısa dönem tepkilerini daha net görmek istememizdir. Söz konusu faktörlerden kaynaklanan şokların etkileri 8- 12 (2-3 yıl ) dönem sonra kaybolmaktadır.

Öncelikle etki tepki analizi bulgularının hata düzeltme modeli sonuçlarıyla büyük ölçüde tutarlılık gösterdikleri söylenebilir. Buna göre; NPLs sanayi üretimi kaynaklı (MPI) şoklara karşı negatif ve istatistiki olarak anlamlı tepki göstermektedir. Sanayi üretiminde meydana gelecek azalma takipteki kredilerin artmasına yol açabilecektir. NPLs'in borsa (Stock) kaynaklı şoklara tepkisinin negatif anacak istatistiki olarak zayıf anlamlılık düzeyinde olduğunu söylenebilir. Bu bulgu, regresyon ve varyans ayrıştırma bulgularıyla tam bir uyumluluk göstermese de hisse senetlerinin değerlerinde meydana gelecek kayıpların takipteki kredileri arttıracağı görüşünü desteklemektedir. NPLs cari açık (CA) kaynaklı şoklara pozitif yönlü ve istatistiki olarak anlamlı tepki vermektedir. Yani cari açık arttığında takipteki kredilerde artış görülmektedir.

Küresel faktörler olarak ifade ettiğimiz ABD2Y ve VIX kaynaklı şoklar karşısında NPLs tepkisi pozitiftir. NPLs'in VIX kaynaklı şoklara tepkisi yüksek USA2Y kaynaklı şoklara tepkisi düşük istatistiki anlamlılık düzeyine sahiptir. Bu bulgular küresel risk iştahını azaltacak gelişmelerin Türkiye'de yabancı sermaye çıkışına neden olarak takipteki kredilerin artmasına yol açabileceği biçiminde açıklanabilir.

Hata düzeltme modeli bulgularına göre NPLs ile aralarında istatistiki olarak anlamsız ilişkiye sahip oldukları saptanan reel kur (REER) ve reel kredi genişlemesi (RCG) değişkenlerinden kaynaklı şoklar karşında NPLs sırasıyla pozitif ve negatif yönlü tepki vermektedir. $\mathrm{Bu}$ sonuçlar literatürle uyumluluk göstermekte olup ve istatistiki olarak anlamlıdırlar. Buna göre döviz kuruna bağlı risk artışları NPLs artışına neden olmaktadır. Yurt içi kredi genişlemesinin zayıflaması karşında ise NPLs negatif yönlü tepki vermektedir. Daha açık olarak kredi hacminin daralması yurt içinde borçların çevrilebilmesini azaltacağından takipteki kredilerin (NPLs) artmasına neden olabilecektir. 


\section{Sonuç ve Değerlendirme}

Türkiye için kredi riskini (NPLs) etkileyen yurt içi ve yurt dişı faktörleri belirlemeye yönelik bu çalışma bulguları birden çok önemli sonuca ulaşmamıza olanak sağlamıştır. Bu faktörleri belirlemek için kullandığımız analiz bulguları büyük ölçüde bir biriyle tutarlılık göstermektedir.

Öncelikle ele alınan değişkenler arasında uzun dönem ilişkinin varlığı veya yokluğunu analiz etmek istediğimiz eş bütünleşme analizi bulguları faktörler arasında uzun dönem ilişkinin varlığına işaret etmektedir. Modelimizdeki bağımsız değişskenlerle NPLs arasında uzun dönem bir ilişkinin olduğu söylenebilir. Yani, cari açık, reel kur, reel kredi genişlemesi, borsadaki fiyat hareketleri, kredi genişlemesi, ekonomik büyüme, sanayi üretimi ve işsizlik uzun dönemde Türkiye'de kredi riskini belirleyen yurt içi faktörler olarak karşımıza çıkmaktadır.

Söz konusu faktörler ile NPLs arasında kısa dönem ilişkinin varlığı ve yönünü araştırmak için ise hata düzeltme modelinden (ECM) yararlanılmıştır. Hata düzeltme modeli bulguları kısa dönem dengesizliklerin uzun dönemde ortadan kalktığına ve modelin kararlı bir model olduğuna işaret etmektedir. Model bulgularına göre, sanayi üretimi, ekonomik büyüme ile takipteki krediler arasında negatif ve istatistiki olarak anlamlı ilişki bulunmuştur. Bu bulgular üretimdeki düşüşün ve gelirdeki azalmanın takipteki kredileri arttığg biçiminde yorumlanabilir. Cari açık ve takipteki krediler arasındaki ilişkinin yönü ise pozitif olarak bulunmuştur. Artan cari açığın yurt içi tüketim artışı sonucu olduğu kabul edildiğinde söz konusu bulgu, tüketimin artışının gerisinde yatan kredi genişlemesinin riskli kredi miktarını arttırabileceği yönünde dolaylı bir etkiyle açıklanabilir. Diğer yandan borsa da yaşanan gelişmeler ile takipteki krediler arasında negatif bir ilişkinin olduğu bulgusuna ulaşılmıştır. Daha açık olarak borsa da meydana gelen olası kayıplar beklendiği gibi takipteki kredilerin artmasına neden olabilecektir. Reel döviz kuru ve reel kredi genişlemesiyle ile takipteki krediler arasında kısa dönemli istatistiki olarak anlamlı ilişkiye rastlanamamış olması beklentilerle uyumsuz olmakla birlikte bu değişkenlerden kaynaklı risklerin uzun dönemde takipteki kredileri arttıracağı bulgusunun önüne geçmemektedir.

Küresel değişkenler ile NPLs arasındaki kısa dönem ilişkinin yönü ise pozitiftir. VIX artışı küresel riskin arttığın anlamına gelmektedir dolayısıyla uluslararası sermaye daha güvenli liman arayışıyla (fly to quality; kaliteye kaçış) gelişmekte olan ülkeleri terk edebilir. USA2Y artışı ABD toparlanama sürecine girdiğinin ya da para politikasında normalleşmenin başladığının işareti olarak algılanmaktadır. Böyle bir durum veya bu yöndeki beklentilerin artması Türkiye gibi gelişmekte olan ülkelerde sermaye çıkışına neden olabilecektir. Her iki durumda da Türkiye gibi ülkelerde sermaye kayıları görülebileceğinden sermaye kayıpları sonrası oluşabilecek likidite darlı̆̆ı veya ödeme güçlüğü bu gibi ülkelerde (Türkiye’de) takipteki kredileri artırabilecektir.

VAR modeline dayalı varyans ayrıştırma hesaplaması ve etki tepki analizi bulguları yukarıdaki açıklamalarımız büyük ölçüde desteklemektedir. Varyans ayrıştırma 
hesaplaması bulguları takipteki kredilerde meydana gelen değişmeleri en fazla açıklama gücüne sahip şokların borsa kaynaklı şoklar olduğunu göstermektedir. Borsa dışında NPLs'deki değişmeleri açıklama gücü en yüksek değişkenler VIX ve ABD2Y olarak karşımıza çıkmaktadır. Küresel finansal gelişmelerin borsalar üzerinde olumlu ya da olumsuz etkilerinin fazla olduğu varsayımı altında varyans ayrıştırmasındaki bulgular bir birini desteklemektedir. Yani, küresel risk iştahındaki bir azalış (VIX artışı) veya ABD para politikasının normalleşmeye döneceği beklentisindeki artış Türkiye gibi gelişmekte olan ülkelerin borsalarını olumsuz etkilemekte ve oluşan sermaye kayıları veya varlık erozyonu takipteki kredilerin artmasına neden olabilmektedir. Elbette USA2Y ve VIX ile STOCK arasındaki ilişki analiz edilirse bu sonucun gerçekçi olup olmadığı açıklık kazanabilir. Bu türden bir ilişki analizi bu çalışmanın ileride genişletilebilmesine olanak verecektir.

Etki tepki analiz bulguları büyük ölçüde kısa dönem regresyon bulgularını desteklemektedir. NPLs, MPI ve STOCK, G ve RCG kaynaklı şoklara tepkisinin negatif yönlü olduğu görülmektedir. Burada regresyon analizinde kısa dönem etkisini göremediğimiz reel kredi genişlemesine takipteki kredilerin negatif yönlü tepki vermesi ilave bir sonuç olarak analizimizi desteklemektedir. Yukarı da açıkladığımız gibi küresel veya yurt içi faktörlere bağlı olarak oluşabilecek yurt içi likidite daralması kredi genişlemesinin azalmasına, reel ve/veya finansal sektörde ödemelerin aksamasına ve takipteki kredilerin artmasına neden olabilecektir. Elbette diğer faktörler ve kredi genişlemesi arasındaki nedensellik analizi yapılırsa söz konusu görüşümüz analiz desteği bulabilir. Böyle bir analizin gerekliliği, yine bu çalışmasının genişletilmesine yönelik bir başka ufuk açmaktadır. NPLs'in reel döviz kuru kaynaklı (REER) şoklara pozitif yönlü tepki vermesi literatüre uyumluluk göstererek analizimizi güçlendiren bir başka ilave bulgu olarak karşımıza çıkmıştır. Kur artışı banka, firma ve hatta hane halkı bilançolarını olumsuz etkileyerek kredilerin ödenmemesine yol açabilecektir. Etki tepki analizine bağlı olarak açıklanabilecek ikinci bir durum küresel faktörler olan VIX ve USA2Y kaynaklı şoklara NPLs tepkisinin pozitif yönlü olmasıdır. Dolayısıyla çalışmanın diğer bulgularıyla bütünlük sağlamakta ve analizi desteklemektedir.

Son olarak yurt içi ekonomide üretim kaybı (MPI ve G ile NPLs arasındaki negatif yönlü ilişki) bankacılık sektörünün kırılganlığını arttırmaktadır. Bu bağlamda ekonomik yavaşlama ve bu yöndeki olumsuz trend aynı zamanda bankacılık sektörünün risklerini yükselttiğinden üretken yatırımları destekleyici politikaların (teknolojik atılım gibi) önemli olduğu düşünülmektedir.

Çalışma bulguları Türkiye'de kredi riskinin küresel finansal faktörlerce etkilendiğini ortaya koymaktadır. Bu faktörler kredi riskini doğrudan ya da dolaylı biçimde, banka bilançoları üzerinden, kur ve faiz riskine bağlı olarak etkilemektedir. Bilanço kaynaklı bu riskler küresel politika değişikliği veya yurt içi makroekonomik dengesizlikler kaynaklı şoklara bağlı olarak finansal ve finansal olmayan kurumlarının bilançolarını bozmakta ve iflasa sürükleyebilmektedirler. 
$\mathrm{Bu}$ bağlamda çalışma bulgularına dayalı ilk önemli çıkarım Türk Bankacılık sektörünün küresel finansal faktörlerin kararlarına veya tepkilerine yüksek bağımlılık göstermesidir. Yurt içi tasarrufların yetersizliğine bağlı olarak geliştiğini düşündüğümüz bu sonuç küresel risklerin bankacılık sisteminin kırılganlığını arttırdığı biçiminde de yorumlanabilir. Çalışma bulgularının banka risklerinin VIX ve USA2Y gibi küresel faktörlere pozitif yönlü ilişki göstermesi bu çıkarımı güçlendirmektedir. Daha açık olarak küresel risk iştahının kapanması (risk off) Türk bankacılık sisteminin riskini arttırmaktadır denilebilir.

IMF (2014) Türkiye raporunda bankacılık sektörünün üstlendiği kur riskinin finansal olmayan kesimlere verdiği döviz cinsinden kredilerin geri dönememe ihtimalinden kaynaklandığı belirtilmiştir. 2014'de Moody's başta olmak üzere uluslararası finansal kuruluşların Türk bankacılık kesiminin üstlendiği kur riskine ilişkin uyarıları da IMF Türkiye raporunu desteklemektedir. Söz konusu ifadeler çalışmanın VAR modeline dayalı olarak elde edilen döviz kuru ve takipteki krediler arasındaki ilişkinin yönünün pozitif olduğu bulgusunu desteklemektedir.

Sonuç olarak çalışmanın literatüre dayanarak oluşturduğu değişkenler matrisi ile takipteki krediler arasında beklenen ilişkileri yakalamıştır denilebilir. USA2Y olarak simgelediğimiz ve ABD kısa vadeli faizleri ve FED politika kararlarına yönelik beklentilerin yansıtıldığını ifade eden değişkendir. USA2Y'ın Türkiye'de takipteki kredileri etkileyen bir değişken olduğuna yönelik bulgunun Türkiye için yapılmış literatüre önemli bir katkı sağladığı düşünülmektedir.

Bu çalışma modelde ihmal edilen işsizlik oranı gibi değişkenlerin veya yukarıda ifade ettiğimiz gibi bağımsız değişkenlerin kendi aralarındaki bağlantı etkilerinin analiziyle genişletilebilecektir. Ayrıca Türkiye ile benzer problemler yaşayan ülkelerin tamamının modele dâhil edilmesiyle bu çalışma panel veri analizi kullanılarak da genişletilebilir.

\section{Kaynaklar}

Akkaya, Y. \& R. Gürkaynak (2012), “Cari Açık, Bütçe Dengesi, Finansal İstikrar ve Para Politikası: Heyecanlı Bir Dönemin İzi”, İktisat, İsletme ve Finans, 27(305), Temmuz, 93-119.

Başç1, E. (2012), "Finansal ve Makroekonomik İstikrar: Önümüzdeki Zorluklar Konferansı”, Açılış

Konuşması, Türkiye Cumhuriyet Merkez Bankası (TCMB), 4 Haziran, İstanbul.

BDDK (2009), “Krizden İstikrara Türkiye Tecrübesi”, Çalışma Tebliği, 2. Baskı, Bankacılık

Düzenleme ve Denetleme Kurumu (BDDK) Strateji Geliştirme Dairesi, Aralık 2009.

BDDK (2010), “Krizden İstikrara Türkiye Tecrübesi”, Çalışma Tebliği, 3. Baskı, Bankacılık

Düzenleme ve Denetleme Kurumu (BDDK) Strateji Geliştirme Dairesi, Eylül 2010.

BDDK (2013), Türk Bankacılık Sektörü Genel Görünümü Eylül 2013, Bankacılık Düzenleme ve Denetleme Kurumu (BDDK), Say1: 2014/1, 12 Kasım.

BDDK (2014), Türk Bankacılık Sektörü Genel Görünümü Aralık 2013, Bankacılık Düzenleme ve Denetleme Kurumu (BDDK), Sayı: 2014/1, 6 Şubat. 
BDDK (2006), Finansal Piyasalar Raporu, Say1 3, Bankacılık Düzenleme ve Denetleme Kurumu (BDDK), Strateji Geliştirme Dairesi, Eylül 2006.

BDDK (2009), Finansal Piyasalar Raporu, Say1 16, Bankac1lık Düzenleme ve Denetleme Kurumu (BDDK), Strateji Geliştirme Dairesi, Eylül 2009.

BDDK (2012), Finansal Piyasalar Raporu, Sayı 27, Bankacılık Düzenleme ve Denetleme Kurumu (BDDK), Strateji Geliştirme Dairesi, Eylül 2012.

BDDK (2012), Finansal Piyasalar Raporu, Say1 28, Bankacılık Düzenleme ve Denetleme Kurumu (BDDK), Strateji Geliştirme Dairesi, Aralık 2012.

Cihak, M. \& K. Schaeck (2007), "How Well Do Aggregate Bank Ratios Identify Banking Problems", IMF Working Paper, 07/275, Monetary and Capital Markets Department, (Washington: International Monetary Fund), December.

De Bock, R. \& A. Demyanets (2012), "Bank Asset Quality in Emerging Markets: Determinants and Spillovers", IMF Working Paper, No: 71, Monetary and Capital Markets, March.

Dell'Ariccia, G. \& D. Igan \& L. Laeven \& H. Tong \& B. Bakker \& J. Vandenbussche (2012), "Policies for Macrofinancial Stability: How the Deal with Credit Booms", IMF Research Department, Staff Discussion Note, Jun 7.

Demirgüç-Kunt, A. \& E. Detragiache (1998), "The Determinants of Banking Crises in Developing and Developed Countries", Staff Papers, (Washington DC: International Monetary Fund), 45(1), 81-109.

Dickey, D. \& W. Fuller (1979), "Distributions of the Estimators for Autoregressive Time Series with a Unit Root", Journal of American Statistical Association, 75, 427-31.

Ebeke, C. \& B. Loko \& A. Viseth (2014), "Credit Quality in Developing Economies: Remittances to the Rescue?", IMF Working Paper, 14/144, African Department, (Washington DC: International Monetary Fund), August.

Enders, W. (1995), Applied Econometric Time Series, John Wiley \& Sons. Inc, New York.

Espinoza, R. \& A. Prasad (2010), "Nonperforming Loans in the GCC Banking Systems and their Macroeconomic Effects", IMF Working Paper, 10/224, Middle East and Central Asia Department, (Washington DC: International Monetary Fund), October.

Fernandez de Lis, S. \& J. Marinez \& S. Jesus (2000), "Credit Growth, Problem Loans and Credit Risk Provisioning in Spain”, Working Paper, No. 0018, Banco de Espana.

Gray, S. \& P. Karam \& V. Meeyam \& M. Stubbe (2014), "Monetary Issues in Middle East and North Africa Region: A Policy Implementation Handbook for Central Bankers", Working Paper, 14/86, Institute for Capacity Development and Monetary and Capital Markets Department, (Washington: International Monetary Fund), May.

International Monetary Fund (2010), Central Banking Lessons from the Crisis, Prepared by the Monetary and Capital Markets Department (Washington DC: International Monetary Fund), May 27.

International Monetary Fund (2013a), “Turkey: 2013 Article IV Consultation”, IMF Country Report, No: 13/363, (Washington DC: International Monetary Fund), December.

International Monetary Fund (2013b), World Economic and Financial Surveys: Global Financial Stability Report: Old Risks, New Challenges, (Washington DC: International Monetary Fund), April.

International Monetary Fund (2014), “Turkey: 2013 Article IV Consultation”, IMF Country Report, No: 14/329, (Washington DC: International Monetary Fund), December. 
Johansen, S. \& K. Juselius (1990), "Maximum Likelihood Estimation and Inference on Cointegration with application to the Demand for Money", Oxford Bulletin of Economics and Statistics, 52, 169-210.

Jakubík, P. \& T. Reininger (2013), "Determinants of Nonperforming Loans in Central, Eastern and Southeastern Europe", Focus on European Economic Integration, Q3/13.

Kim, K. \& S. Mitra (2014), "Real and Financial Vulnerabilities from Crossborder Banking Linkages", IMF Working Paper, 14/136, Monetary and Capital Markets Department, (Washington DC: International Monetary Fund), July.

Klein, N. (2013), "Non-Performing Loans in CESEE: Determinants and Impact on Macroeconomic Performance", IMF Working Paper, 13/72, European Department, (Washington DC: International Monetary Fund), March. International Monetary Fund), May.

Lütkepohl, H. \& P. Saikkonen \& C. Trenkler (2000), "Maximum Eigenvalue versus Trace Test for the Cointegrating Rank of a VAR Process", The Econometrics Journal, 4(2).

Makri, V. \& A. Tsagkanos \& A. Bellas (2014), "Determinants of Non-Performing Loans: The Case of Eurozone", Panoeconomicus, 2, 193-206.

Moody's (2014), "Rating Action: Moody's Reviews for Downgrade the Ratings of 10 Turkish Banks", Global Credit Research, 18 March 2014.

Navajas, M.C. \& A. Thegeya (2013), "Financial Soundness Indicators and Banking Crises", IMF Working Paper, 13/263, (Washington DC: International Monetary Fund), Statistics Department, December.

Nkusu, M. (2011), "Nonperforming Loans and Macrofinancial Vulnerabilities in Advanced Economies", IMF Working Paper, 11/161, Strategy, Policy, and Review Department, (Washington: International Monetary Fund), July.

Pouvelle, C. (2012), "Bank credit, Asset Prices and Financial Stability: Evidence from French Banks”, IMF Working Paper, 12/103, European Department, (Washington DC: International Monetary Fund), April.

TCMB (2010), Finansal İstikrar Raporu, Türkiye Cumhuriyet Merkez Bankası (TCMB), Sayı: 11, Aralık.

Valencia, F. (2011), "Monetary Policy, Bank Leverage, and Financial Stability", IMFWorking Paper, 11/244, (Washington DC: International Monetary Fund), October.

Vazquez, F. \& M. Tabak Benjamin \& M. Souto (2010), “A Macro Stress Test Model of Credit Risk for the Brazilian Banking Sector”, Banco Central do Brasil, Working Paper Series, 226. 
EK: 1

Etki - Tepki Analiz Bulguları

NPLs - MPI Tepkisi

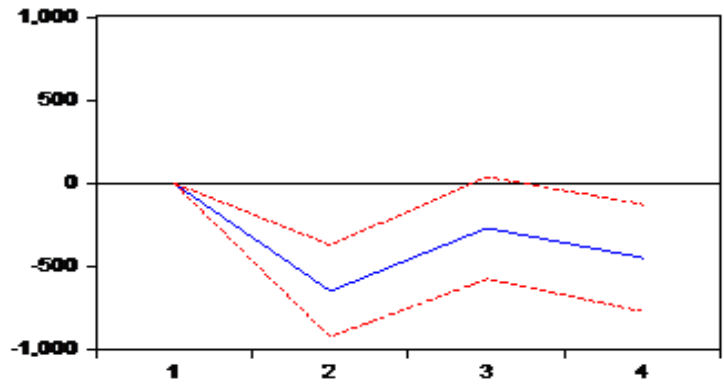

NPLs - Stock Tepkisi

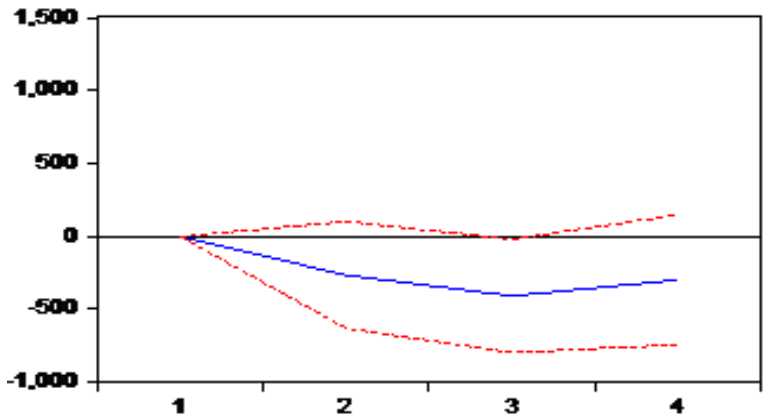

NPLs - CA Tepkisi

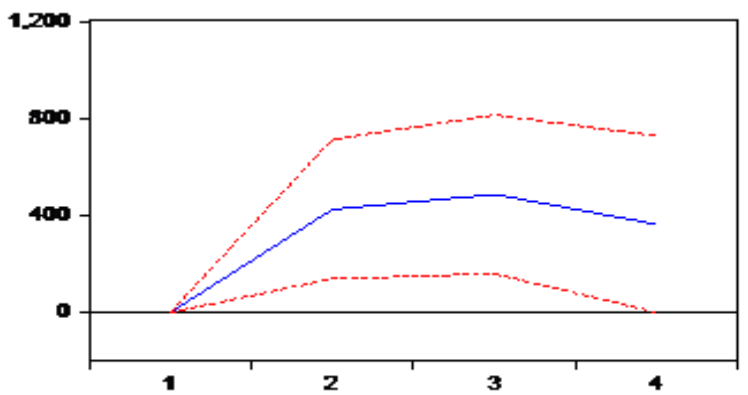




\section{NPLs - G Tepkisi}

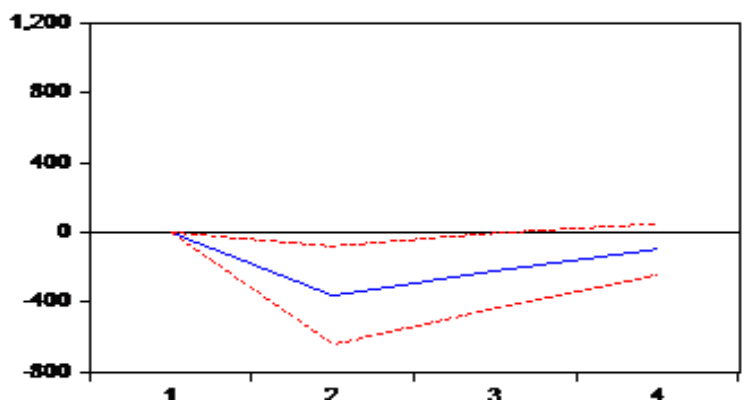

\section{NPLs - VIX Tepkisi}

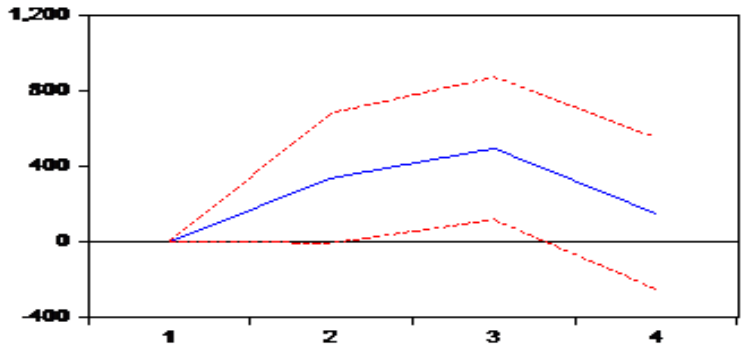

NPLs -USA2Y Tepkisi

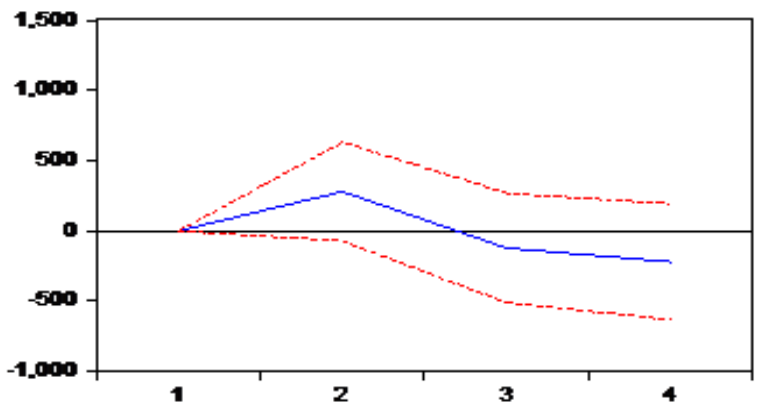


Demirel, B. (2016), “Türk Bankacılık Sisteminde Kredi Riski ve Modellenmesi”, Sosyoekonomi, Vol. 24(29), 23-44.

\section{NPLs - REER Tepkisi}
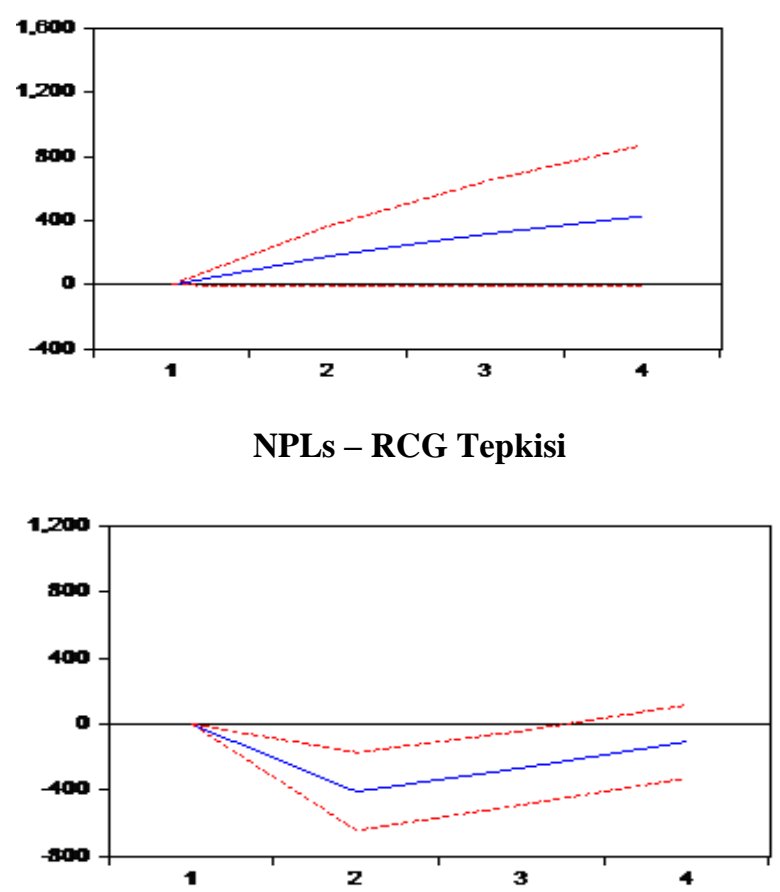
EK: 2

Korelasyon Sonuçları

Ek Tablo: 1

Korelâsyon Test Sonuçları

\begin{tabular}{|c|c|c|c|c|c|c|c|c|c|}
\hline NPI S & NPLS & G & CG & RER & MPI & $\mathrm{CA}$ & STOCK & USA2Y & VIX \\
\hline G & $\begin{array}{l}1,00 \\
-0,08\end{array}$ & 1,00 & & & & & & & \\
\hline CG & $0,37 * *$ & 0,12 & 1,00 & & & & & & \\
\hline RER & 0,22 & $-0,07$ & $-0,02$ & 1,00 & & & & & \\
\hline MPI & $0,31 * *$ & 0,19 & 0,06 & $-0,35 * *$ & 1,00 & & & & \\
\hline CA & $0,55 * * *$ & 0,20 & 0,12 & $-0,22$ & 0,23 & 1,00 & & & \\
\hline STOCK & $0,88 * * *$ & 0,07 & 0,20 & $0,42 * *$ & $0,30 * *$ & $-0,67 * * *$ & 1,00 & & \\
\hline USA2Y & $0,74 * * *$ & 0,06 & $0,30 * *$ & 0,07 & $-0,47$ & $0,37 * *$ & $-0,50 * *$ & 1,00 & \\
\hline VIX & 0,07 & $-0,16$ & $0,45 * *$ & 0,06 & $-0,26$ & 0,09 & $-0,22$ & $0,35^{* *}$ & 1,00 \\
\hline
\end{tabular}

Ek Tablo: 2

Oto-Korelasyon Test Sonuçları

\begin{tabular}{|c|c|c|c|c|c|c|}
\hline 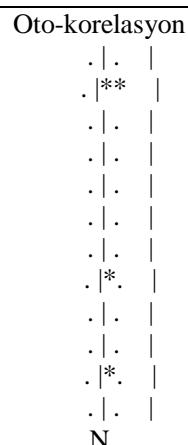 & 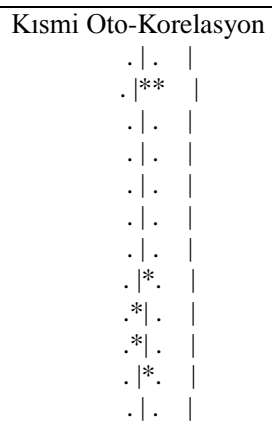 & $\begin{array}{c}1 \\
2 \\
3 \\
4 \\
5 \\
6 \\
7 \\
8 \\
9 \\
10 \\
11 \\
12\end{array}$ & $\begin{array}{c}\mathrm{AC} \\
0.002 \\
0.246 \\
0.008 \\
0.047 \\
-0.037 \\
-0.050 \\
0.026 \\
0.132 \\
-0.058 \\
-0.013 \\
0.081 \\
-0.034\end{array}$ & $\begin{array}{c}\text { PAC } \\
0.002 \\
0.246 \\
0.008 \\
-0.015 \\
-0.044 \\
-0.062 \\
0.049 \\
0.172 \\
-0.078 \\
-0.099 \\
0.114 \\
-0.014\end{array}$ & $\begin{array}{l}\text { Q-Stat } \\
0.0001 \\
2.8570 \\
2.8599 \\
2.9687 \\
3.0403 \\
3.1691 \\
3.2065 \\
4.1689 \\
4.3580 \\
4.3685 \\
4.7690 \\
4.8412\end{array}$ & $\begin{array}{l}\text { Olasilik } \\
0.992 \\
0.240 \\
0.414 \\
0.563 \\
0.694 \\
0.787 \\
0.865 \\
0.842 \\
0.886 \\
0.929 \\
0.942 \\
0.963\end{array}$ \\
\hline
\end{tabular}

Not: Null-Slfir Hipotezi oto korelasyon yoktur biçimindedir. 


\section{EK: 3}

Türk Bankacılık Sektörü Performans Göstergeleri (2002-2013)

Grafik: 1

\section{Bankacılık Sektörü Ana Performans Oranları}

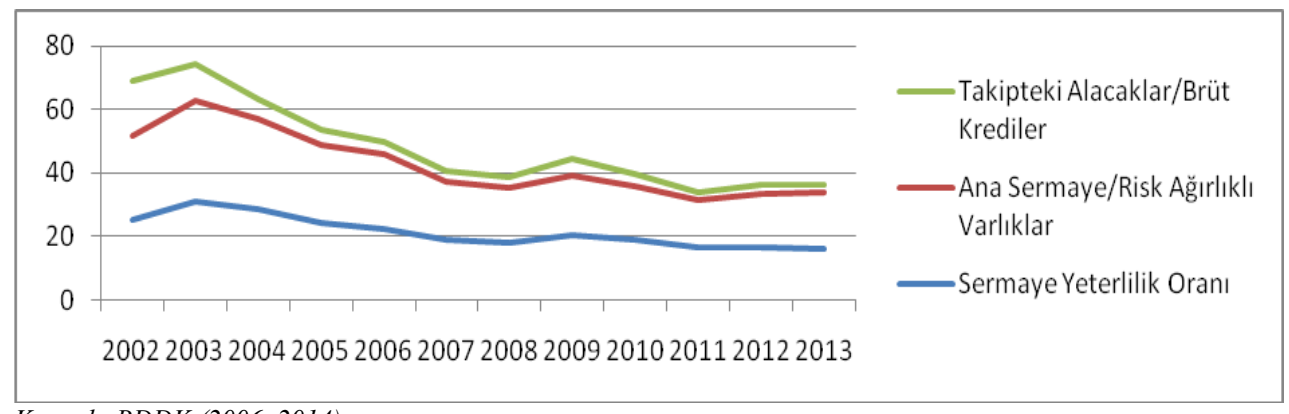

Kaynak: BDDK (2006, 2014).

Grafik: 2

Net Özkaynak Karılı̆̆ğı (2002-2013)

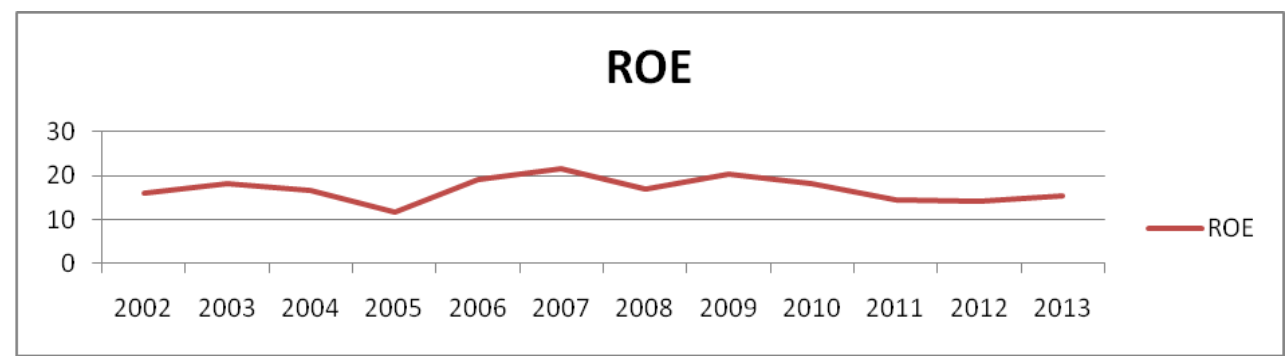

Kaynak: BDDK (2006, 2014).

Grafik: 3

Net Aktif Karlılığı (2002-2013)

\section{ROA}

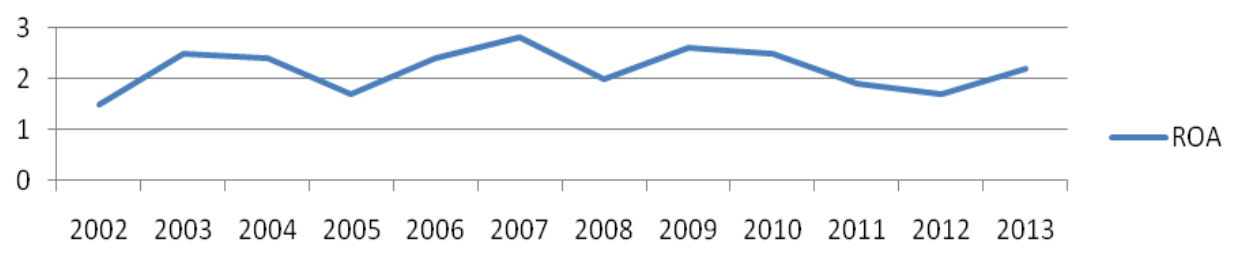

Kaynak: BDDK (2006, 2014). 